\title{
Difference on Capital Allocation and Operating Performance-Evidence from China Listed Companies
}

\author{
Jianfeng Zhao \\ School of Economics and Management, Shanxi University, Taiyuan, China \\ Email: zhaojian@sxu.edu.cn
}

How to cite this paper: Zhao, J.F. (2018) Difference on Capital Allocation and Operating Performance-Evidence from China Listed Companies. American Journal of Industrial and Business Management, 8, 2200-2208.

https://doi.org/10.4236/ajibm.2018.811147

Received: October 25, 2018

Accepted: November 19, 2018

Published: November 22, 2018

Copyright $\odot 2018$ by author and Scientific Research Publishing Inc. This work is licensed under the Creative Commons Attribution International License (CC BY 4.0).

http://creativecommons.org/licenses/by/4.0/

\begin{abstract}
The neoclassical theory of investment has been developed to explain, in a perfect market, the investment decision of a company depends on the net present value of a project, and its expenditure is determined only by the set of investment opportunities, and independent of other factors. However, in reality, other factors influence investment mostly. For the full sample of China listed companies, capital allocation is consistent with operating performance. Controlling property rights of the enterprises, we show that various kinds of investments in state-owned listed companies are inconsistent with operating performance, but non-state-owned listed companies reflect effective investment. In the long run, deepening classified reform of state-owned enterprises is extremely demanded.
\end{abstract}

\section{Keywords}

Capital Allocation, Operating Performance, Classified Reform

\section{Introduction}

In recent years, China economic growth has shifted and decreased, and the government and enterprises gradually have realized that investment as the most important factor plays a "double-edged sword" effecting economic growth. Investment forms current demand, driving the current economic development, and constitutes future supply ability, affecting economic growth and economic structure. In other words, investment promotes economic development through short-term demand effect and long-term supply effect together, otherwise the simple pursuit model of investment scale to expand demand growth must highlight the dual problems of investment path dependence and economic growth 
quality predicament (Hao Ying, et al., 2014) [1]. Reasoningly understanding and correctly utilizing the supply effect of investment is particularly important in the current supply-side reform, and is also the path to China economic growth by investment in New Normal.

Enterprises are the main body of investment behavior. Supply effect of investment is the output effect of enterprise investment on macro-economy, and promotes the long-term growth of the national economy from multi-level wave transmission modes. The supply effect of investment is an economic concept with rich connotation and needs a normative value judgment. The core of the value judgment is to ensure high quality and effective future supply of investment projects with operating performance constraints. In China, under new backgrounds of national development strategy, the relationship between enterprise investment differences and operating performance becomes one of the important topics for further study. So is the supply effect of Chinese investment on economy positive or negative? Are Chinese enterprises investments high in quality? The paper analyses Chinese enterprises' investments and performance deeply, then finds problems and countermeasures in terms of theory and practice.

The paper proceeds as follows. Section 2 presents our theory of investment and research design. Section 3 presents full-sample results, and Section 4 compares results across different types of firms, and Section 5 concludes.

\section{Theoretical Analysis and Research Design}

\subsection{Decision Criteria for Capital Allocation}

In a perfect market, the investment decision of a company depends on the net present value of a project, and its expenditure is determined only by investment opportunity sets, and independent of other factors (Modigliani and Mille, 1958) [2]. Hayashi (1982) theoretically proved that under the assumption of perfect market, the optimal capital expenditure of a company is the function of marginal $\mathrm{Q}$ [3]. It has also been the judgment of project investing in corporate financial theory, namely when making investment decisions, expected future cash flows should be discounted at the capital cost of the project, and the discount rate depends on size of the project, future cash flows and its risk. Only when the project in the future can provide sustained, stable and realistic cash flows, after actual execution the investment produce enough and effective supply of high quality to meet social demand. As the first major decision of corporate finance, the high quality capital investment decision must be conducive to create enterprise value and increase shareholders' wealth. Based on these, capital allocation of listed companies is positively correlated with operating performance. The current accounting standards classify capital investment as equity investment, fixed assets, intangible assets and development expenditure by function and character, thus the following three hypotheses are proposed:

H1-1: Equity investment in listed companies is positively correlated with op- 
erating performance.

H1-2: Fixed assets investment in listed companies is positively correlated with operating performance.

H1-3: Intangible investment in listed companies is positively correlated with operating performance.

\subsection{Research on the Influence Factors of Capital Allocation}

In the real world, however, due to asymmetric information, agency conflict and so on, company operating environment may make important influence on enterprise investment decisions for managers, which affects efficiency of capital allocation and enterprise value (Jensen and Meckling, 1976) [4]. National development strategy, external governance environment factors (Li Yanxi, et al., 2015) [5] and other macroeconomic environment factors, industry competition (Chen Xinyuan, et al., 2013) [6], industry characteristics (Pan Yuxiang, et al., 2015) [7] and other medium industry factors, control power gain grabbing drive (Zhang Shuo and Zhao Xi, 2016) [8], equity concentration (Song Xiaobao) [9], manager features, management power (Wang Maolin, 2014) [10], bank-enterprise relations (Zhai Shengbao, et al., 2014) [11] and other more corporate internal characteristics all will affect enterprise investment strategy.

When studying Chinese enterprises, we can't ignore the characteristic of property rights. In China, the government has the strong control ability to state-owned enterprises, where state-owned enterprises have huge advantages in getting resources (such as financing, project bidding, etc.) relative to non-stateowned enterprises. As the main participants of economic activities, the main business goals should also be to promote enterprise value, therefore, in the capital allocation, they should be based on investment efficiency as the judgment standard, so as to promote the improvement of operating performance. Based on these, the following three hypotheses are proposed for the capital allocation in state-owned listed companies:

$\mathrm{H} 2-1$ : Equity investment in state-owned listed companies is positively correlated with operating performance.

H2-2: Fixed assets investment in state-owned listed companies is positively correlated with operating performance.

H2-3: Intangible investment in state-owned listed companies is positively correlated with operating performance.

The non-state-owned listed companies are built according to the modern enterprise system, and flourishing in the process of marketalization, where the resource allocation is naturally optimal. At the same time, in non-state-owned listed companies underinvestment is mainly manifested with serious financing constraints. In order to obtain financing, enterprises also choose projects with better expected investment returns. Based on these, the following three hypotheses are proposed for the capital allocation in non-state-owned listed companies: 
H3-1: Equity investment in non-state-owned listed companies is positively correlated with operating performance.

H3-2: Fixed asset investment in non-state-owned listed companies is positively correlated with operating performance.

H3-3: Intangible investment in non-state-owned listed companies is positively correlated with operating performance.

\subsection{Study Design}

1) Sample and data

Our sample includes all listed companies in Chinese A stock market. We also exclude firms with missing or non-positive book value of relevant accounts, and where index calculation value is invalid (for instance, the denominator is zero), as is standard in the literature. Considering the financial crisis of 2008-2013, we use data from 2014 to 2016 in CSMAR database. Finally the full sample is 422 . We winsorize regression variables at the $1 \%$ level to remove extreme outliers.

2) Model assumption and variable description

Perf $=\alpha+\beta_{1}(\Delta M A / M A)+\beta_{2}(\Delta F i x / F i x)+\beta_{3}(\Delta$ Int $/$ Int $)+\beta_{4}$ Size $+\beta_{5}$ Lev $+\varepsilon$

The above multiple linear regression model is established. The dependent variable is operating performance (Perf), which uses the weighted average return on equity after deducting non-recurring gains and losses. There are three independent variables, namely, the growth rate of equity investment $(\triangle M A / M A)$, the growth rate of fixed asset investment $(\Delta F i x / F i x)$ and the growth rate of intangible investment $(\Delta I n t / I n t) . \triangle M A$ is the change value of equity investment in the current period, $M A$ is the beginning value of equity investment in the current period, $\Delta F i x$ is the change value of fixed asset investment in the current period, Fix is the beginning value of fixed asset investment in the current period, fixed assets investment includes net value of fixed assets, engineering materials and net value of construction in process; $\Delta I n t$ is the change value of intangible investment, Int is the beginning value of intangible investment, including intangible assets investment and the average $\mathrm{R} \& \mathrm{D}$ expenditure. The control variable adopts the enterprise Size (Size) and financial leverage (Lev) at the end of the term (Table 1).

\section{Capital Allocation Differences on Performance Test}

\subsection{Correlation Analysis}

The correlation analysis results of full sample in the model are shown in Table 2. There is a significant positive correlation between equity investment and operating performance, fixed asset investment is so. The correlation coefficient of intangible investment on operating performance is positive, but not significant. In terms of control variables, there are significant linear correlations between enterprise scale, financial leverage and operating performance. In addition, the values of variance expansion factor of each variable are less than 5 , which are far 
Table 1. Definition of model variables.

\begin{tabular}{cl}
\hline Symbol & \multicolumn{1}{c}{ Definition of variables } \\
\hline Perf & the weighted average return on equity after deducting non-recurring gains and losses \\
$\Delta M A / M A$ & the growth rate of equity investment \\
$\Delta F i x / F i x$ & the growth rate of fixed asset investment \\
$\Delta$ Int/Int & the growth rate of intangible investment \\
Size & the enterprise Size at the end of the term \\
Lev & financial leverage at the end of the term
\end{tabular}

Table 2. Correlation analysis of full sample.

\begin{tabular}{|c|c|c|c|c|c|c|c|}
\hline & & $\triangle M A / M A$ & $\Delta F i x / F i x$ & $\Delta$ Int/ Int & Size & Lev & Perf \\
\hline \multirow{2}{*}{$\triangle M A / M A$} & $\mathrm{r}$ & 1 & $-0.155^{\star *}$ & -0.019 & -0.002 & $-0.160^{\star *}$ & $0.120^{*}$ \\
\hline & $\mathrm{t}$ & & 0.001 & 0.690 & 0.970 & 0.001 & 0.014 \\
\hline \multirow{2}{*}{$\Delta F i x / F i x$} & $\mathrm{r}$ & $-0.155^{* *}$ & 1 & 0.035 & 0.025 & 0.022 & $0.108^{*}$ \\
\hline & $\mathrm{t}$ & 0.001 & & 0.474 & 0.606 & 0.653 & 0.027 \\
\hline \multirow{2}{*}{$\Delta$ Int/Int } & $\mathrm{r}$ & -0.019 & 0.035 & 1 & 0.011 & 0.089 & 0.061 \\
\hline & $\mathrm{t}$ & 0.690 & 0.474 & & 0.817 & 0.067 & 0.210 \\
\hline \multirow{2}{*}{ Size } & $\mathrm{r}$ & -0.002 & 0.025 & 0.011 & 1 & $0.498^{* *}$ & $0.258^{\star *}$ \\
\hline & $\mathrm{t}$ & 0.970 & 0.606 & 0.817 & & 0.000 & 0.000 \\
\hline \multirow{2}{*}{ Lev } & $\mathrm{r}$ & $-0.160^{\star *}$ & 0.022 & 0.089 & $0.498^{* *}$ & 1 & $-0.135^{\star *}$ \\
\hline & $\mathrm{t}$ & 0.001 & 0.653 & 0.067 & 0.000 & & 0.005 \\
\hline \multirow{2}{*}{ Perf } & $\mathrm{r}$ & $0.120^{*}$ & $0.108^{\star}$ & 0.061 & $0.258^{\star *}$ & $-0.135^{\star *}$ & 1 \\
\hline & $\mathrm{t}$ & 0.014 & 0.027 & 0.210 & 0.000 & 0.005 & \\
\hline
\end{tabular}

Note: ${ }^{*} 1 \%$ significant level; ${ }^{*} \%$ significant level.

less than 10, indicating that there are no multiple mutual problems among the variables.

\subsection{Regression Analysis Results}

$\mathrm{R}^{2}$ is $18.4 \%$ in the model, and the fitting degree of the model is better. Regression results are shown in Table 3, equity investment, fixed assets investment and intangible investment on operating performance have significant positive correlations respectively, showing that the higher the capital growth is, the better operating performance, hypotheses H1-1, H1-2, H1-3 are verified.

\section{The Regulating Effect of Property Rights on Capital Allocation}

Controlling property rights of an enterprise, when the ultimate controlling owner of the sample company is the state-owned assets supervision and administration commission of the state council, a state-owned enterprise or other state organ, the value is 1 , otherwise 0 . In this way, the sample of state-owned listed companies is 120 , and the others of 302 are non-state-owned listed companies. 
Table 3. Coefficient of full sample.

\begin{tabular}{|c|c|c|c|c|c|c|}
\hline & \multirow{2}{*}{ Model } & \multicolumn{2}{|c|}{ Non standardized coefficients } & \multirow{2}{*}{$\begin{array}{c}\text { Standard } \\
\text { coefficient } \\
\text { trial version }\end{array}$} & \multirow{2}{*}{$\mathrm{t}$} & \multirow{2}{*}{ Sig. } \\
\hline & & B & standard error & & & \\
\hline \multirow{6}{*}{1} & (constant) & -82.594 & 10.918 & & -7.565 & 0.000 \\
\hline & $\triangle M A / M A$ & 0.104 & 0.056 & 0.085 & 1.863 & 0.063 \\
\hline & $\Delta F i x / F i x$ & 3.413 & 1.331 & 0.115 & 2.563 & 0.011 \\
\hline & $\Delta \operatorname{Int} \mid \operatorname{Int}$ & 0.257 & 0.135 & 0.085 & 1.901 & 0.058 \\
\hline & Size & 4.320 & 0.522 & 0.425 & 8.279 & 0.000 \\
\hline & Lev & -18.276 & 2.780 & -0.343 & -6.574 & 0.000 \\
\hline
\end{tabular}

Note: Dependent: Perf.

\subsection{State-Owned Listed Companies}

In Table 4 for the subsample of state-owned listed companies, the relation between equity investment and operating performance is not significantly correlated, fixed assets investment and intangible investment are so, and the Pearson correlation coefficient of equity investment and operating performance is negative, H2-1, H2-2, H2-3 are not verified. In state-owned listed companies, there is no significant linear relationship between capital allocation and operating performance, which shows that the increase of capital does not bring the increase of operating performance, and capital allocation do not agree with operating performance. State-owned enterprises are the mixtures of administration management and market. Besides the pursuit of performance, they take into account tax, employment and social stability, and many other targets. Corresponding to these, senior executives are appointed and appraised by economic factors, political factors, social responsibility and other factors. Under multiple targets of state-owned enterprises, operating performance is not the sole decision criteria for selecting an investment project. Therefore, investment surplus or underinvestment occurs, and the investment efficiency is not high.

\subsection{Non-State-Owned Listed Companies}

In Table 5 of the sample of non-state-owned listed companies, there is a significant positive correlation between equity investment and operating performance, fixed assets investment is so, and the correlation coefficient between intangible investment and operating performance is positive, but not significant. There are also significant linear relationships between enterprise scale, financial leverage and operating performance in control variables.

In the model design, $\mathrm{R}^{2}$ is $20 \%$, and the fitting degree of the model is better. As shown in Table 6, equity investment, fixed assets investment, intangible investment and operating performance are significantly positively correlated respectively, in non-state-owned listed companies the higher growth of capital allocation, the better operating performance, and every capital allocation is consistent with enterprise performance, hypotheses of H3-1, H3-2, H3-3 are verified. 
Table 4. Pearson correlation analysis in state-owned listed companies.

\begin{tabular}{|c|c|c|c|c|c|c|c|}
\hline & & $\triangle M A / M A$ & $\Delta F i x / F i x$ & $\Delta I n t / I n t$ & Size & Lev & Perf \\
\hline \multirow{2}{*}{$\triangle M A / M A$} & $\mathrm{r}$ & 1 & $-0.404^{\star \star}$ & $-0.227^{\star}$ & 0.006 & -0.089 & -0.047 \\
\hline & $\mathrm{t}$ & & 0.000 & 0.013 & 0.946 & 0.334 & 0.612 \\
\hline \multirow{2}{*}{$\Delta F i x / F i x$} & $\mathrm{r}$ & $-0.404^{\star *}$ & 1 & $0.408^{* *}$ & -0.045 & 0.063 & 0.029 \\
\hline & $\mathrm{t}$ & 0.000 & & 0.000 & 0.626 & 0.496 & 0.750 \\
\hline \multirow{2}{*}{$\Delta$ Int/ Int } & $\mathrm{r}$ & $-0.227^{*}$ & $0.408^{* *}$ & 1 & $0.218^{*}$ & 0.132 & 0.130 \\
\hline & $\mathrm{t}$ & 0.013 & 0.000 & & 0.017 & 0.150 & 0.157 \\
\hline \multirow{2}{*}{ Size } & $\mathrm{r}$ & 0.006 & -0.045 & $0.218^{*}$ & 1 & $0.482^{* *}$ & $0.317^{* *}$ \\
\hline & $\mathrm{t}$ & 0.946 & 0.626 & 0.017 & & 0.000 & 0.000 \\
\hline \multirow{2}{*}{ Lev } & $\mathrm{r}$ & -0.089 & 0.063 & 0.132 & $0.482^{* *}$ & 1 & -0.052 \\
\hline & $\mathrm{t}$ & 0.334 & 0.496 & 0.150 & 0.000 & & 0.575 \\
\hline \multirow{2}{*}{ Perf } & $\mathrm{r}$ & -0.047 & 0.029 & 0.130 & $0.317^{\star *}$ & -0.052 & 1 \\
\hline & $t$ & 0.612 & 0.750 & 0.157 & 0.000 & 0.575 & \\
\hline
\end{tabular}

Note: ${ }^{*} 1 \%$ significant level, ${ }^{*} \%$ significant level.

Table 5. Pearson correlation analysis in non-state-owned listed companies.

\begin{tabular}{|c|c|c|c|c|c|c|c|}
\hline & & $\triangle M A / M A$ & $\Delta F i x / F i x$ & $\Delta \operatorname{Int} / \operatorname{In} t$ & Size & Lev & Perf \\
\hline \multirow{2}{*}{$\triangle M A / M A$} & $\mathrm{r}$ & 1 & $-0.128^{\star}$ & -0.016 & 0.012 & $-0.174^{\star *}$ & $0.152^{\star *}$ \\
\hline & $\mathrm{t}$ & & 0.026 & 0.779 & 0.841 & 0.002 & 0.008 \\
\hline \multirow{2}{*}{$\Delta$ Fix/Fix } & $\mathrm{r}$ & $-0.128^{\star}$ & 1 & 0.026 & 0.063 & 0.026 & $0.125^{\star}$ \\
\hline & $\mathrm{t}$ & 0.026 & & 0.648 & 0.272 & 0.647 & 0.030 \\
\hline \multirow{2}{*}{$\Delta$ Int/Int } & $\mathrm{r}$ & -0.016 & 0.026 & 1 & 0.007 & 0.106 & 0.065 \\
\hline & $\mathrm{t}$ & 0.779 & 0.648 & & 0.900 & 0.066 & 0.259 \\
\hline \multirow{2}{*}{ Size } & $\mathrm{r}$ & 0.012 & 0.063 & 0.007 & 1 & $0.471^{\star *}$ & $0.254^{\star *}$ \\
\hline & $\mathrm{t}$ & 0.841 & 0.272 & 0.900 & & 0.000 & 0.000 \\
\hline \multirow{2}{*}{ Lev } & $\mathrm{r}$ & $-0.174^{\star \star}$ & 0.026 & 0.106 & $0.471^{\star *}$ & 1 & $-0.164^{* *}$ \\
\hline & $\mathrm{t}$ & 0.002 & 0.647 & 0.066 & 0.000 & & 0.004 \\
\hline \multirow{2}{*}{ Perf } & $\mathrm{r}$ & $0.152^{\star \star}$ & $0.125^{\star}$ & 0.065 & $0.254^{* *}$ & $-0.164^{\star *}$ & 1 \\
\hline & $\mathrm{t}$ & 0.008 & 0.030 & 0.259 & 0.000 & 0.004 & \\
\hline
\end{tabular}

Note: ${ }^{*} 1 \%$ significant level, ${ }^{*} \% \%$ significant level.

\subsection{Robustness Test}

There are many indicators to express operating performance. The above results have been demonstrated by Perf. In order to improve our study, the robustness test is carried out here. We change Perf of the dependent variable to ROA (net profit/total assets) to describe operating performance. The results of the robustness test are consistent with the previous conclusions. 
Table 6. Coefficient of the model in non-state-owned listed companies.

\begin{tabular}{|c|c|c|c|c|c|c|}
\hline & \multirow{2}{*}{ model } & \multicolumn{2}{|c|}{ Non standardized coefficient } & \multirow{2}{*}{$\begin{array}{c}\text { Standard } \\
\text { coefficient }\end{array}$} & \multirow[t]{2}{*}{$\mathrm{t}$} & \multirow{2}{*}{ Sig. } \\
\hline & & B & Standard error & & & \\
\hline \multirow{6}{*}{1} & (constant) & -88.144 & 13.962 & & -6.313 & 0.000 \\
\hline & $\triangle \mathrm{MA} / \mathrm{MA}$ & 0.114 & 0.060 & 0.102 & 1.901 & 0.058 \\
\hline & $\Delta$ Fix/Fix & 3.290 & 1.456 & 0.119 & 2.259 & 0.025 \\
\hline & $\Delta \mathrm{Int} / \mathrm{Int}$ & 0.261 & 0.139 & 0.098 & 1.876 & 0.062 \\
\hline & Size & 4.620 & 0.668 & 0.412 & 6.918 & 0.000 \\
\hline & Lev & -20.074 & 3.437 & -0.354 & -5.841 & 0.000 \\
\hline
\end{tabular}

Note: Dependent: Perf.

\section{Conclusions and Implications}

For the full sample, the capital allocation of listed companies in China is consistent with the operating performance. Equity investment, fixed assets investment, intangible investment are basically effective, but the relationship between intangible investment and operating performance is relatively weak, which shows that the intangible investment efficiency is low, according with the uncertainty feature of the innovation.

In state-owned listed companies, various kinds of investment are inconsistent with operating performance. Choosing investment projects is not in accordance with investment optimization, against the enterprise goal, in the long run, which is bad for enterprise development, and deepening the reform of state-owned enterprises is extremely demanded. Based on the strategic positioning and development objective of state-owned capital, combined with different state-owned enterprises roles in the economic and social development, the present situation and needs, according to the main business and core business scopes, state-owned enterprises are classified into two categories of business class and public class. Reforming State-owned enterprises should be carried out by enterprise character, improve the corporate governance structure, optimize the layout of state-owned capital and strengthen supervision of state-owned assets. According to the tasks undertook and the social development request, state-owned enterprises of the public class should strengthen state-owned capital investment, improve the quality and efficiency of public services, strictly limit their main business scopes, strengthen main business management, and focus on providing public products and services to make greater contribution. State-owned enterprises of business class should optimize the resources allocation, intensify restructuring, integration and $\mathrm{R} \& \mathrm{D}$ expenditure, speed up the pace of technology and management innovation, persistently promote the transformation and upgrading, and foster a batch of state-owned backbone enterprises with innovation capacity and international competitiveness. In this way, the classification reform will better promote the preservation and appreciation of state-owned capital.

In non-state-owned listed companies, various investments are consistent with 
business performance, which reflects the effective investment of non-state-owned listed companies. Private enterprises are the important part of the national economy, and different from state-owned enterprises. Non-state-owned enterprises have generally clear property rights, relatively perfect modern corporate governance structure, and investment standard consistent with enterprise goal to achieve the optimal resource allocation for healthy and efficient enterprise development. Therefore, with the further development of market economy, the whole society should create a good investment and financing environment to promote the continuous growth of private enterprises for realizing the optimal allocation of all the social resources.

\section{Conflicts of Interest}

The author declares no conflicts of interest regarding the publication of this paper.

\section{References}

[1] Hao, Y., Xin, Q.Q. and Liu, X. (2014) Regional Difference, Enterprise Investment and Quality of Economic Growth. Economic Research, No. 3, 101-115.

[2] Modigliani, F. and Miller, M.H. (1958) The Cost of Capital, Corporation Finance and the Theory of Investment. American Economic Review, 48, 261-297.

[3] Hayashi, F. (1982) Tobin's Marginal q and Average q: A Neoclassical Interpretation. Econometrica, 50, 213-224. https://doi.org/10.2307/1912538

[4] Jensen, M.C. and Meckling, W.H. (1976) Theory of the Firm: Managerial Behavior, Agency Costs and Ownership Structure. Journal of Financial Economics, 3, 305-360. https://doi.org/10.1016/0304-405X(76)90026-X

[5] Li, Y.X., et al. (2015) External Governance Environment, Ownership and Efficiency of Listed Companies' Investment. Nankai Business Review, No. 1, 25-36.

[6] Chen, X.Y., et al. (2013) Industry Competition, Managerial Investment, and Equity Value of Growth/Put Options. China Economic Quarterly, No. 10, 305-332.

[7] Pan, Y.X., et al. (2015) The Research of the Relationship between Managers' Characteristics and Their Investment Decision in Cultural Creative Enterprises. China Soft Science, No. 3, 172-181.

[8] Zhang, S. and Zhao, X. (2016) Change in Capital Allocation and Private Benefit Expropriation-Evidence from Control Right Transaction in Chinese Listed Firms. Accounting Research, No. 12, 44-51.

[9] Song, X.B. (2013) Ownership Concentration, Investment Decision and Agency Cost. Chinese Journal of Management Science, 21, 152-161.

[10] Wang, M.L., He, Y.R. and Lin, H.T. (2014) Managerial Power, Cash Dividends and Enterprises' Investment Efficiency. Nankai Business Review, No. 2, 13-22.

[11] Zhai, S.B., et al. (2014) The Study on the Relationship between the Banking Connection and the Investment Efficiency of Listed Company. Accounting Research, No. 4, 74-81. 